\title{
SEISMIC DESIGN AND PERFORMANCE OF COMPOSITE FRAMES
}

\author{
G. Thermou ${ }^{1}$, A.S. Elnashai ${ }^{2}$, A. Plumier $^{3}$ \\ ${ }^{1}$ Department of Civil Engineering, Democritus University of Thrace (D.U.Th.), Greece \\ ${ }^{2}$ Department of Civil Engineering - Newmark Labs, University of Illinois (U.I.U.C.), U.S.A. \\ ${ }^{3}$ Department of Civil Engineering, University of Liege (ULg), Belgium
}

\begin{abstract}
In this study, the seismic design and performance of composite steel-concrete frames are studied. The new Eurocode 4 and Eurocode 8, which are in a preliminary stage at the moment, are employed for the design of six composite steel-concrete frames. The deficiencies of the codes and the clauses that cause difficulties to the designer are discussed. The inelastic static pushover analysis is employed for obtaining the response of the frames and the overstrength factors. The evaluation of the response modification factor takes place by performing incremental time-history analysis up to the satisfaction of the yield and collapse limit states in order to investigate the conservatism of the code. The last purpose of this study is to investigate if elastically designed structures can behave in a dissipative mode.
\end{abstract}

Keywords: Composite Frames, F.E. Modelling, Force Reduction Factor, Overstrength, Inelastic Static Pushover Analysis, Incremental Time-History Analysis

\section{INTRODUCTION}

In this paper, the drafts of the new Eurocode 4 (1994-1-1:2001) and Eurocode 8 (1998-1$1: 2001)$ are utilized for the design of six composite steel-concrete frames. The frames are divided into two groups; the first set of frames is designed for a composite slab, while the second is designed for a solid concrete slab. The objective is to chronicle all the difficulties faced during the design procedure. The confusing clauses and the deficiencies of the code are recorded.

The next step involves the analysis phase, where the finite element program INDYAS is utilized. Inelastic static pushover analysis is employed for obtaining the response of the frames and the overstrength factors. After the definition of the performance criteria and the input ground motions, incremental time-history analysis is performed for the case of the second set of frames (solid slabs) up to the satisfaction of the yield and collapse limit states. The evaluation of the behaviour or force reduction factor takes place. Two different definitions are employed, one of which takes into account the observed overstrength. The purpose of this part is to identify the importance of including the overstrength factor in the definition of the behaviour factor, the conservatism of the code suggested behaviour factor values and if structures designed elastically will behave in an inelastic mode. 


\section{DESIGN OF COMPOSITE STEEL-CONCRETE FRAMES}

Six composite steel concrete frames are designed, according to the new Drafts of EC3 (19931-1:2000), EC4 (1994-1-1:2001) and EC8 (1998-1-1:2001). The first configuration of each set, (A), is a 2D, four-storey, four-bay moment resisting frame. The designed frame is an internal frame of a four-span of $4 \mathrm{~m}$ in $\mathrm{x}$ and $\mathrm{y}$ direction building. The bay length is $4 \mathrm{~m}$ and the storey height is $3.5 \mathrm{~m}$. The live load is $3.5 \mathrm{kN} / \mathrm{m}^{2}$. The beams and columns are composite. In the case of the composite slab, the steel sheeting is placed transverse to the beam. This frame is designed according to the new drafts of EC3 and EC4. The second configuration of each frame, (B), is a 2D, four-storey, four-bay moment resisting frame in medium seismicity region $(\mathrm{PGA}=0.2 \mathrm{~g})$. The geometry and the load settings are taken the same as in the first configuration. Only the translation mode is considered. The design follows the guidelines of the new Draft of EC8. The third configuration, $(\mathrm{C})$, is a 2D, eight-storey, four-bay moment resisting frame in a high seismicity region $(\mathrm{PGA}=0.4 \mathrm{~g})$. The same setting for the geometry and the load as in the second configuration apply. The design is carried out according to the new Draft of EC8. The same material properties are used in all cases. The concrete grade is $\mathrm{C} 30 / 37\left(\mathrm{f}_{\mathrm{yk}}=30 \mathrm{MPa}\right)$, the steel of the reinforcing bars is $\mathrm{S} 400\left(\mathrm{f}_{\mathrm{yk}}=400 \mathrm{MPa}\right)$ and the structural steel grade is Fe510 $\left(\mathrm{f}_{\mathrm{yks}}=355 \mathrm{MPa}\right)$.

The columns of the frames are partially encased. The composite beams are not encased and two types are employed; the first type has a composite slab, while the second one has a solid slab.
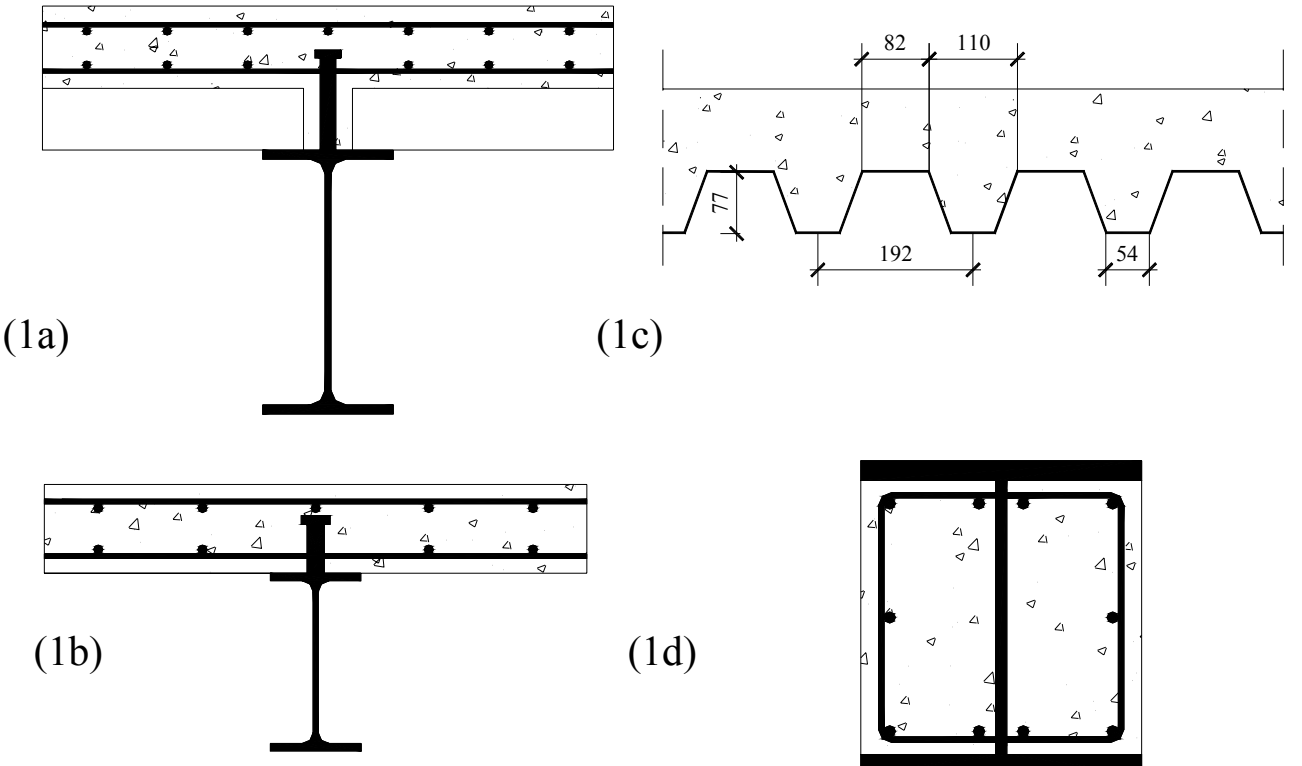

(1c)

(1d)

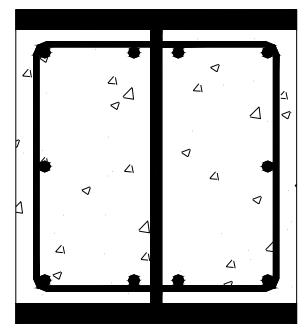

Figure 1: Cross-sections types used in the design.

In general, using a composite slab has the feature that the distance between troughs determines the minimum spacing between the stud connectors. In the case, this number of stud connectors is not enough to satisfy the shear connection check (full shear connection), then, one way to solve this problem is to stop the steel sheeting at the beam. This solution allows putting as many shear connectors as required, since all the relevant clauses of minimum distance are satisfied. This procedure has been followed in the design of the first set of frames. As it can be seen from Figure 1a, the steel sheeting stops at the beam. The code 
provides some limitations on the bearing length of the steel sheeting. According to Clause 9.2.3 (Draft EN 1994-1-1:2001) the bearing length shall be such that damage to the slab and the bearing is avoided, that fastening of the sheet to the bearing can be achieved without damage to the bearing and that collapse cannot occur as a result of accidental displacement during erection. For composite slabs bearing on steel, which is the case, the bearing length should not be less than $1_{\mathrm{bs}}=50 \mathrm{~mm}$ (Figure 2).

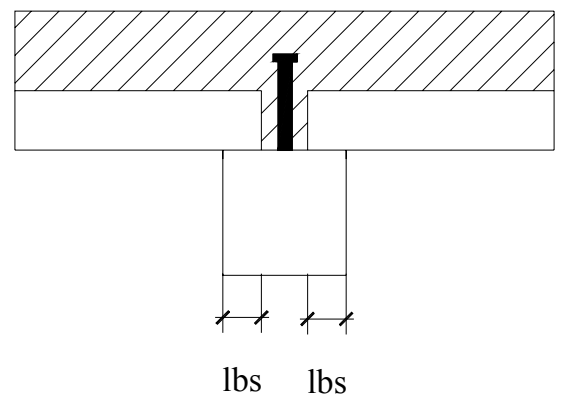

Figure 2: Minimum bearing lengths.

Following this solution, a limitation is imposed on the selection of the steel beam cross-section. The flange width should be at least $150 \mathrm{~mm}$, since a gap of 50 mm of concrete shall encase the stud connector (Figure 2). Hence, the size of the beam is determined by this constructional reason. The minimum steel beam cross section then is the IPE300, which has a flange width equal to $150 \mathrm{~mm}$. For each frame of the first set, the design starts with a restriction on the beam size, which, as it is shown later, governs the design.

The type of composite column used is the partially concrete encased I-section (Figure 1d). The concrete is gripped by transverse reinforcement, which is anchored to the steel section by stirrups passing through the web.

In the design phase, the frames are designed first according to EC4 (prEN 1994-1-1:2001) and then EC8 (prEN 1998-1-1:2001) is applied. All the clauses that may cause difficulties to the designer have been recorded (Table 1, Table )

Beginning with EC4, the solid slab has been designed as a reinforced concrete slab according to EC 2 (prEN 1992-1:January 2001). By using this type of slab, no limitation is imposed on the spacing of shear connectors. The height of the solid slab is taken in the design equal to $100 \mathrm{~mm}$. On the other hand, the composite slab has been designed according to Chapter 9, "Composite slab with profiled steel sheeting for buildings", which deals with composite floor slabs spanning only in the direction of the ribs. The chosen profiled steel sheeting is the Super-Floor 77. The thickness of the steel sheeting is $1 \mathrm{~mm}$ and its characteristics are presented in Figure 1c. The height of the composite slab used is $180 \mathrm{~mm}$. The composite slab is checked for the Ultimate and the Serviceability limit state. Full shear connection is assumed and for the determination of the bending resistance of any cross section, the plastic theory is adopted.

The design of composite beams involves two stages; the construction stage and the composite stage. In the construction stage, the beams are sized first to support the self-weight of the concrete and other construction loads. In the composite stage, the resistance of composite sections is usually carried out using plastic analysis. The composite beams with a composite slab are assumed as simply supported in the construction stage, since the steel sheeting stops at the beam. In the composite stage that concrete has been purred and has developed its strength the composite beam is considered continuous.

Composite columns and composite compression members are designed according to Clause 6.7 (prEN 1994-1-1:2001). The simplified method for members of double symmetrical and uniform cross-section over the member length is adopted for the design of the frames. 


\begin{tabular}{|c|c|}
\hline \multicolumn{2}{|r|}{ Main deficiencies observed in EC4 (prEN 1994-1-1:2001) } \\
\hline \multicolumn{2}{|r|}{ (a) Design of Composite Slabs } \\
\hline Clause 9.7.3 & $\begin{array}{l}\text { The definition of the shear span length for the case of a continuous beam is } \\
\text { different from that of the previous code (ENV 1994-1-1:1992). The } \\
\text { symbols used to describe the equivalent isostatic span and how this is } \\
\text { related to the shear span length should? be revised. A figure illustrating to } \\
\text { what these lengths correspond would be very helpful for the designer. }\end{array}$ \\
\hline $\begin{array}{l}\text { Clauses 5.5.1, } \\
\text { 7.4.1(9), 7.4.2(1), } \\
\text { 7.3.2(1) }\end{array}$ & $\begin{array}{l}\text { There are many available clauses for the minimum reinforcement of the } \\
\text { concrete flange. This is not practical and causes confusion to the designer. }\end{array}$ \\
\hline \multicolumn{2}{|r|}{ (b) Design of Composite Beams } \\
\hline Clause 6.2.1.2 (2) & $\begin{array}{l}\text { There is a reduction in the design resistance moment } \mathrm{M}_{\mathrm{Rd}} \text { in case the } \\
\text { distance } \chi_{\mathrm{pl}} \text { between the plastic neutral axis and the extreme fibre of the } \\
\text { concrete slab in compression exceeds a percentage of the overall depth } \mathrm{h} \text { of } \\
\text { the member. This clause does not explain the necessity of this reduction or } \\
\text { what the certain limits given represent. }\end{array}$ \\
\hline Clause 6.4 & $\begin{array}{l}\text { The lateral-torsional buckling check need to be revised. The calculation of } \\
\text { the elastic critical moment of the composite section } \mathrm{M}_{\mathrm{cr}} \text { is difficult. The } \\
\text { guideline suggests using specialist literature or numerical analysis. }\end{array}$ \\
\hline Clause 6.4.3 & $\begin{array}{l}\text { In the "Simplified verification for buildings without direct calculation" } \\
\text { procedure, some conditions are given for designing without additional } \\
\text { lateral bracing. Condition (b) is not very clear, especially in the case of } \\
\text { seismic design. Some improvement describing in detail what is meant by } \\
\text { "design permanent load" and "total load" is required. }\end{array}$ \\
\hline \multicolumn{2}{|r|}{ (c) Design of Composite Columns } \\
\hline Clause 6.7.3.2(5) & $\begin{array}{l}\text { A polygonal diagram for simplification reasons replaces the interaction } \\
\text { curve. There is no description of the steps that have to be followed in order } \\
\text { to generate the interaction curve. An annex explaining in detail the } \\
\text { parameters involved in the calculation of the interaction curve and the } \\
\text { theory behind it is required. }\end{array}$ \\
\hline Clause 6.7.3.6 & $\begin{array}{l}\text { In the calculation of the resistance of a composite member in combined } \\
\text { compression and uniaxial bending the factor } \mu_{\mathrm{d}} \text {, which refers to the design } \\
\text { plastic resistance moment } \mathrm{M}_{\mathrm{pl}, \mathrm{Rd}} \text { for the plane of bending being considered, } \\
\text { is defined graphically, without any additional explanation. There is no } \\
\text { alternative for taking imperfections into account. }\end{array}$ \\
\hline Clause 6.7.4.2(6) & $\begin{array}{l}\text { Where stud connectors are attached to the web of a concrete encased steel } \\
\text { I-section, account may be taken of the frictional forces that develop from } \\
\text { the prevention of lateral expansion of the concrete by the adjacent steel } \\
\text { flanges. The additional resistance is assumed to be } \mu \mathrm{P}_{\mathrm{RD} / 2} \text { on each flange } \\
\text { and each row, where } \mu \text { is the relevant coefficient of friction and } \mathrm{P}_{\mathrm{Rd}} \text { is the } \\
\text { resistance of a single stud. This resistance remains constant independently } \\
\text { of the number and rows of stud connectors. Further explanation shall be } \\
\text { given on why this resistance is kept constant. }\end{array}$ \\
\hline
\end{tabular}

Table 1: Main deficiencies observed in EC4 (prEN 1994-1-1:2001).

For the first time a new Chapter for the design of composite steel-concrete frames is included in the new draft of Eurocode 8. The frames are designed according to "Concept a", with design rules that aim at the development in the structure of reliable plastic mechanisms (dissipative zones) and of a reliable global plastic mechanism dissipating as much energy as possible under the design earthquake action. Specific criteria aim at the development of a design objective that is a global mechanical behaviour. For design "concept a", two structural ductility classes, I (Intermediate) and S (Special), are defined. They correspond to an 
increased ability of the structure to dissipate energy through plastic mechanisms. A structure belonging to a given ductility class has to meet specific requirements in one or more of the following aspects: structural type, class of steel sections, rotational capacity of connections, and detailing.

The frames being regular in plan and elevation are analyzed according to the "Simplified modal response analysis". The behaviour factor for the four-storey buildings and for the eightstorey buildings have been selected to be $\mathrm{q}=4$ and $\mathrm{q}=6$, respectively (Clause 7.3 .2 (1)).

The role of floor slabs during an earthquake is to connect vertical elements together and distribute the seismic forces to the lateral load-resisting system. Diaphragms and bracings in horizontal planes shall be able to transmit with sufficient overstrength the effects of the design seismic action to the various lateral load-resisting systems to which they are connected.

Composite beams should comply with the additional rules defined in Chapter 7 of Eurocode 8. The earthquake resistant structure is designed with reference to a global plastic mechanism involving local dissipative zones. The preferable mechanism is the beam mechanism, having "strong columns and weak beams". The formation of plastic hinges is allowed at the end of the beams and at the base of the ground storey columns. This concept is realized in the requirements of EC8 by applying the capacity design method.

A fundamental principle of capacity design is that plastic hinges in columns should be avoided. To achieve this, column design moments are derived from equilibrium conditions at beam column joints, taking into account the actual resisting moments of beams framing into the joint. Moreover, columns play a significant role in the control of the interstorey drift.

\begin{tabular}{|l|l|}
\hline \multicolumn{2}{|c|}{ Main deficiencies observed in EC8 (prEN 1998-1-1:2001) } \\
\hline \multicolumn{3}{|c|}{ (a) Design of Composite Slabs } \\
\hline Clause 4.5.2.5 & $\begin{array}{l}\text { Diaphragms and bracings in horizontal planes shall be able to transmit with } \\
\text { sufficient overstrength the effects of the design seismic action to the } \\
\text { various lateral load-resisting systems to which they are connected. The } \\
\text { latter is considered satisfied if for the relevant resistance verifications the } \\
\text { forces obtained from the analysis are multiplied by a factor equal to 1.3. } \\
\text { The last suggestion about increasing the forces obtained from the analysis } \\
\text { by 30\% in order to achieve needs a further explanation, for example, for } \\
\text { which type of analysis and what this increase represents. }\end{array}$ \\
\hline \multicolumn{1}{|c|}{ (b) Design of Composite Beams } \\
\hline Clause 7.6.2(8) & $\begin{array}{l}\text { The code imposes some limitations on the ratio x/d of the distance } \mathrm{x} \\
\text { between the top concrete compression fibre and the plastic neutral axis to } \\
\text { the depth of the composite section, in order to achieve ductility in plastic } \\
\text { hinges. Though less restrictive than in EC4, these values are still very } \\
\text { requiring and in the examined cases have never been satisfied. The code } \\
\text { does not provide the designer with an alternative. A revision should be } \\
\text { made on these values and maybe some experiments would be necessary to } \\
\text { support the future selected values. }\end{array}$ \\
\hline
\end{tabular}

Table 2: Main deficiencies observed in EC8 (prEN 1998-1-1:2001).

The analysis is performed with the program "Sap2000 Nonlinear". It is one of the most reliable commercial programs with lot of abilities. This program does not include composite sections in its library. The section type used to model the behaviour of the composite sections is the "General" section type. These properties for a composite beam are calculated by using 
an equivalent steel cross section, whereas for the composite column the code gives a formula for the evaluation of the stiffness.

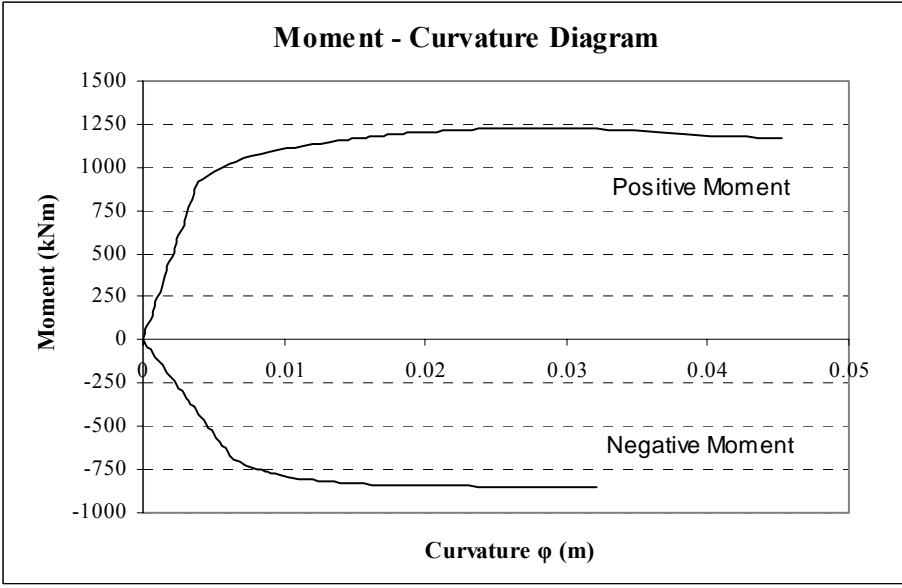

Figure 3: Behaviour of composite section in positive and negative moment.
The use of the "General" section for modelling the behaviour of the composite beam has the disadvantage that assumes a uniform behaviour in negative and positive moment. That means that the capacity of the beam is the same, independently of the sign of the moment. The section in reality shall behave as shown in Figure 3 In addition, the negative second moment of area is not constant along the beam, as it has been considered. In positive moment, the second moment of area is greater than the one developed in negative moment.

\section{PRE-REQUISITES FOR MODELLING AND ANALYSIS}

The computer programme "INDYAS" has been developed at Imperial College (Elnashai, Pinho, Antoniou, 2001), to provide an efficient tool for the nonlinear analysis of two- and three-dimensional reinforced concrete, steel and composite structures under static and dynamic loading, taking into account the effects of both geometric nonlinearities and material inelasticity. The programme has the feature of representing the spread of inelasticity within the member cross-section and along the member length through utilizing the fibre approach. It is capable of predicting the large inelastic deformation of individual members and structures. A variety of analyses may be used ranging from dynamic time-history, static time-history, inelastic static pushover, adaptive pushover and static with non-variable loading.

The concrete model used in the analyses is a nonlinear concrete model with constant (active) confinement modelling ("con2"). The model of Mander et al. (1998) has a good balance between simplicity and accuracy. A constant confining pressure is assumed taking into account the maximum transverse pressure from confining steel. The bilinear elasto-plastic model is used to describe the behaviour of steel. It is a simple model where the elastic range remains constant throughout the various loading stages, and the kinematic hardening rule for the yield surface is assumed to be linear function of the increment of plastic strain (Elnashai, Elghazouli, 1993). The composite slab and the reinforced concrete slab of the composite beam section are modelled with the reinforced concrete rectangular section (rcrs), the steel beam, which is an I-section, with the symmetric I- or T-section (sits) and the composite column with the partially encased composite section I-section (pecs).

The cubic elasto-plastic element is selected to model the behaviour of the composite beams and columns. This formulation assumes a cubic shape function in the chord system, and monitor stresses and strains at various points across two Gaussian sections, allowing the spread of plasticity throughout the cross section. The fibre approach is used in the evaluation of the response parameters. The cross-section is divided into a number of layers dependent on the desired accuracy. In addition, the number of cubic elasto-plastic elements per member plays a significant role in the required level of accuracy. Six degrees of freedom are used in 
the 3D analysis (Figure 4), whereas three degrees of freedom are employed in the 2D analysis. The calculation of the transverse displacement is given by the cubic shape function:

$$
\mathrm{v}(\mathrm{x})=\left(\frac{\theta_{1}+\theta_{2}}{\mathrm{~L}^{2}}\right) \mathrm{x}^{3}-\left(\frac{2 \theta_{1}+\theta_{2}}{\mathrm{~L}}\right) \mathrm{x}^{2}+\theta_{1} \mathrm{x}
$$

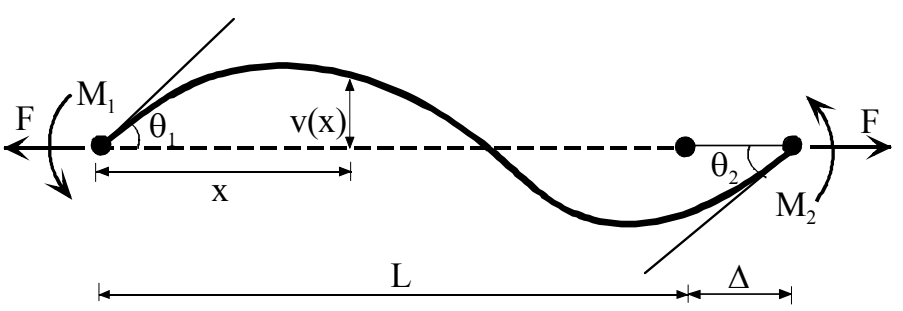

Figure 4: Chord freedoms of the cubic formulation.

The integration of the virtual work equation to obtain the element forces is performed numerically. Along the length of the element two Gauss integration sections are employed. Each Gauss section is divided into a number of areas across which stresses and strains are monitored.

The joint element models the behaviour of those reinforcing bars of the slab which correspond to the column flange length and are assumed to be welded on the column flange. For the complete definition of the joint element, three nodes are required. Nodes 1 and 2 are the end nodes of the element and must be initially coincident, while node 3 is only used to define the $\mathrm{x}$-axis of the joint and can be either a structural or non-structural node. The force-deformation relationship employed for each degree of freedom is the trilinear symmetric curve.

It has been considered that the masses are concentrated in the nodes. From the library of INDYAS the concentrated (lumped) mass element is used. The inertia forces are developed at nodes.

The material properties of the concrete and structural steel employed in the analysis are shown inTable 3:

\begin{tabular}{|c|c|c|}
\hline \multicolumn{2}{|r|}{ Material parameter } & Values used in analysis \\
\hline \multirow{4}{*}{ 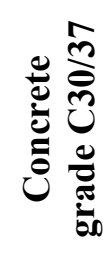 } & Compressive strength, $f_{\text {ck }}$ & $30 \mathrm{~N} / \mathrm{mm}^{2}$ \\
\hline & Tensile strength, $f_{c t}$ & $0.001 \mathrm{~N} / \mathrm{mm}^{2}$ \\
\hline & Crushing strain, $\varepsilon_{\mathrm{c}}$ & 0.0022 \\
\hline & Modulus of elasticity, $E_{c}$ & $32836 \mathrm{~N} / \mathrm{mm}^{2}$ \\
\hline \multirow{4}{*}{ 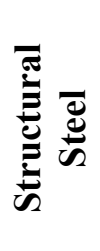 } & Yield strength, $\mathrm{f}_{\mathrm{y}}$ & $355 \mathrm{~N} / \mathrm{mm}^{2}$ \\
\hline & Ultimate strength, $f_{u}$ & $510 \mathrm{~N} / \mathrm{mm}^{2}$ \\
\hline & Strain-hardening parameter & 0.005 \\
\hline & Young's modulus, $E_{s}$ & $210,000 \mathrm{~N} / \mathrm{mm}^{2}$ \\
\hline
\end{tabular}

Table3: Material properties employed in the assessment.

Composite beams consist of two parts, the composite or solid concrete slab and the steel beam. Each part is modelled with the cubic elasto-plastic element. Because full shear 
connection is assumed, these two parts shall be connected in such a way, that slippage in the interface is avoided. Therefore, the two parts are connected with "rigid links". These are cubic elasto-plastic elements. Their length is equal to the distance between the centroids of the steel beam and the composite or solid slab. The model of a simply supported beam spanning four meters (Figure 5) is used in order to define the properties of the "rigid links".

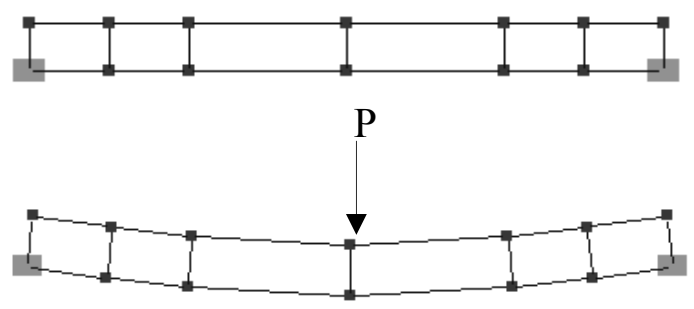

Figure5: Simply supported beam used to define the rigid link properties.

The "rigid links" shall ensure that the two parts of the composite beam will behave in the same way. They shall play the role of the stud connectors. Some parametric study has been carried out, aiming at having the same deflection and rotation between the upper and the lower node of each "rigid link". An error of about 5-10\% has been accepted. The results are used to model the behaviour of all the "rigid links".

A description of the way in which the slab, the steel beam and the full shear connection are modelled is presented inFigure 6 . The length of the rigid links depends on the distance between the centroids of the steel beam and the slab.
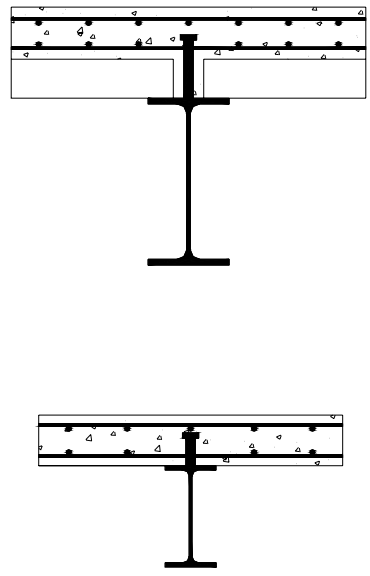

Cross - section

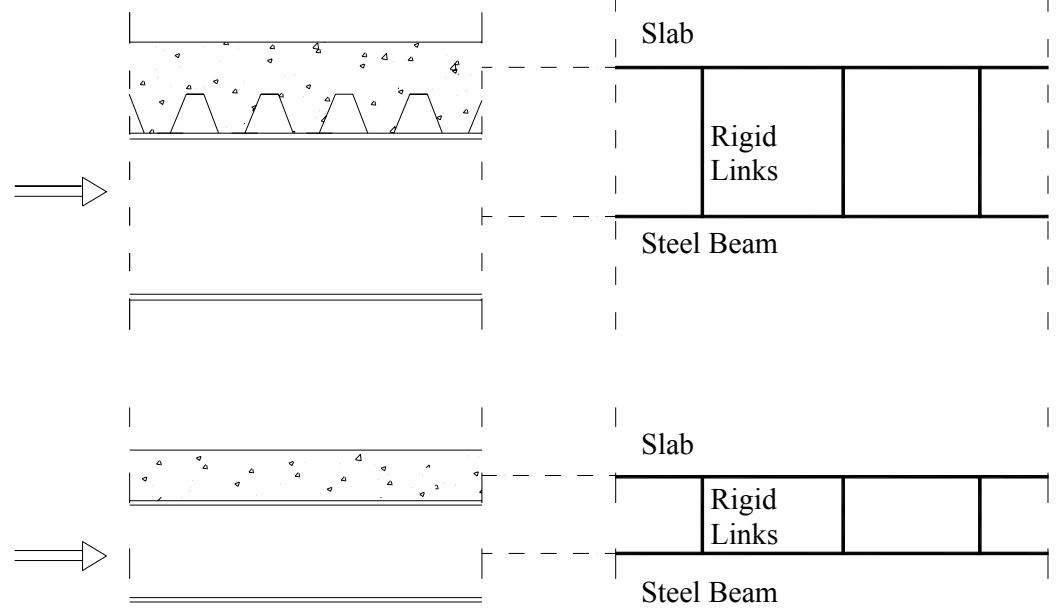

Elevation
F.E. Model

Figure6: Modelling of the two types of composite beams.

As it can be seen fromFigure 5, each composite beam is divided into six segments. At the beam-ends, the length of the segments is shorter, in order to have a more detail information in the region of the formulation of the plastic hinges. There are five "rigid links" in each beam.

The connection between the composite beam and column is fixed. The steel beam is rigidly connected to the column, whereas the slab is connected to the column with a joint element. 
The joint element models the behaviour of those reinforcing bars of the slab which correspond to the column flange length and are assumed to be welded on the column flange (Figure 7).

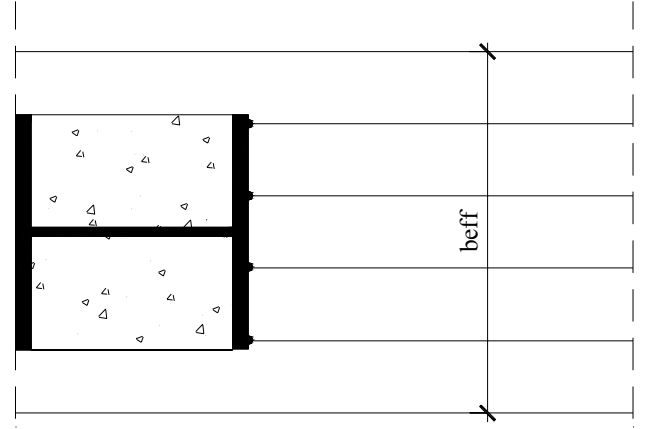

Figure7: Detailing of the reinforcement. are fixed to the ground.
The initial distributed loads are applied as point loads at all the nodes along the beam length. The mass is placed at the joints, where the steel beam is connected with the column.

Composite columns are modelled also with cubic elasto-plastic elements. Each column is divided into five segments. In the case of inelastic static pushover analysis, the proportional load is applied as lateral load at the points where the column is connected to the beam. The first storey columns

To assess the seismic performance of composite frames from the inelastic static and dynamic analysis results, a set of criteria is defined. These performance criteria correspond to yield and to collapse limit state. In this study, only the global criteria related to the drift are taken into account. For code-designed steel and composite structures, especially when EC8 is used, local limit states are unlikely to govern. Therefore, only global response criteria are employed.

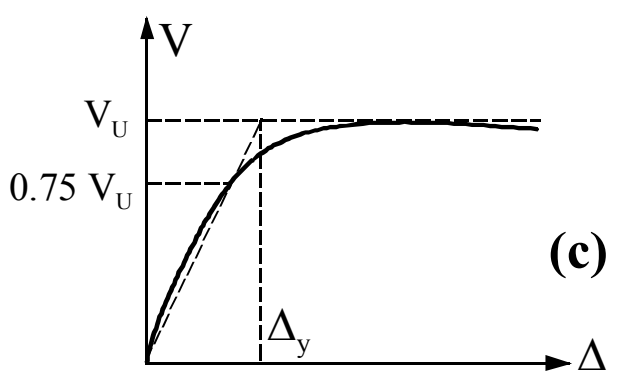

Figure8: Global Yield Limit.

The definition of the yield point on the actual forcedeformation envelope is a rather complicated matter. The global yield displacement is defined by assuming a reduced stiffness evaluated as the secant stiffness at $75 \%$ of the ultimate strength is assumed. The postelastic branch is defined by the ultimate lateral strength of the real system.

COMMENT: in Fig 8, is it Vu or Vy? in Fig 9, it is $\mathrm{Vy}$, which is in my view the correct symbol.

When assessing the overall structural characteristics, the interstorey drift ratio is considered as one of the most important global collapse criterion. Imposing an upper limit on the acceptable storey drift, the limitation of the structural and non-structural damage during a seismic event is controlled. The definition of the maximum allowable value of the interstorey drift ratio is not unique for all the types of structures. In addition, it depends on what performance levels have to be satisfied. The main task is, in any case, to avoid significant P- $\Delta$ effects, which lead to failure. Overestimating the collapse criterion can lead to a gross error in the assessment of the seismic response and the force reduction factors. Hence, a conservative upper limit is adopted, the value of which is 3\%. This upper limit, recommended in previous studies (Broderick, 1994; Broderick and Elnashai, 1995), is sufficient to restrict the P- $\Delta$ effects and to limit the damage in structural and non-structural elements.

GENERAL COMMENT FOR WHAT FOLLOWS

The developments about q factors are much, much too long. In fact, they should correspond to a second paper. In that case, there would be time and space to deal properly with the problem; It is not the case here. Most of the symbols used are not properly or not at all defined (did you read the text, Amr?). Some symbols used are not those of EC8, which makes reading uselessly difficult for someone familiar with EC8 (for instance, why not use $\alpha \mathrm{u} / \alpha 1$ instead of the invented symbol $\Omega \mathrm{d}$ ? 
My opinion is that the paper is too long and will not correspond to the editor requirement. I suggest to rewrite the development on q's and $\Omega$ 's, just using the standard definitions and coming out with the conclusion that, following the complete design process, for the structures considered, there is overstrength here are the numbers. Serious conclusions about q's and $\Omega$ 's would require a more extensive study. I do not want to question EC8 on the narrow basis given.

As it is well known, every seismic code bases its prescriptions on the assumption that, during severe earthquakes, any designed structure will be able to dissipate a large part of the energy input through plastic deformations. The value of the behaviour factor mainly depends on the ductility of the structure (which relates to the detailings of the structural members), on the strength reserves that normally exist in a structure (depending mainly on its redundancy and on the overstrength of individual members) and on the damping of the structure.

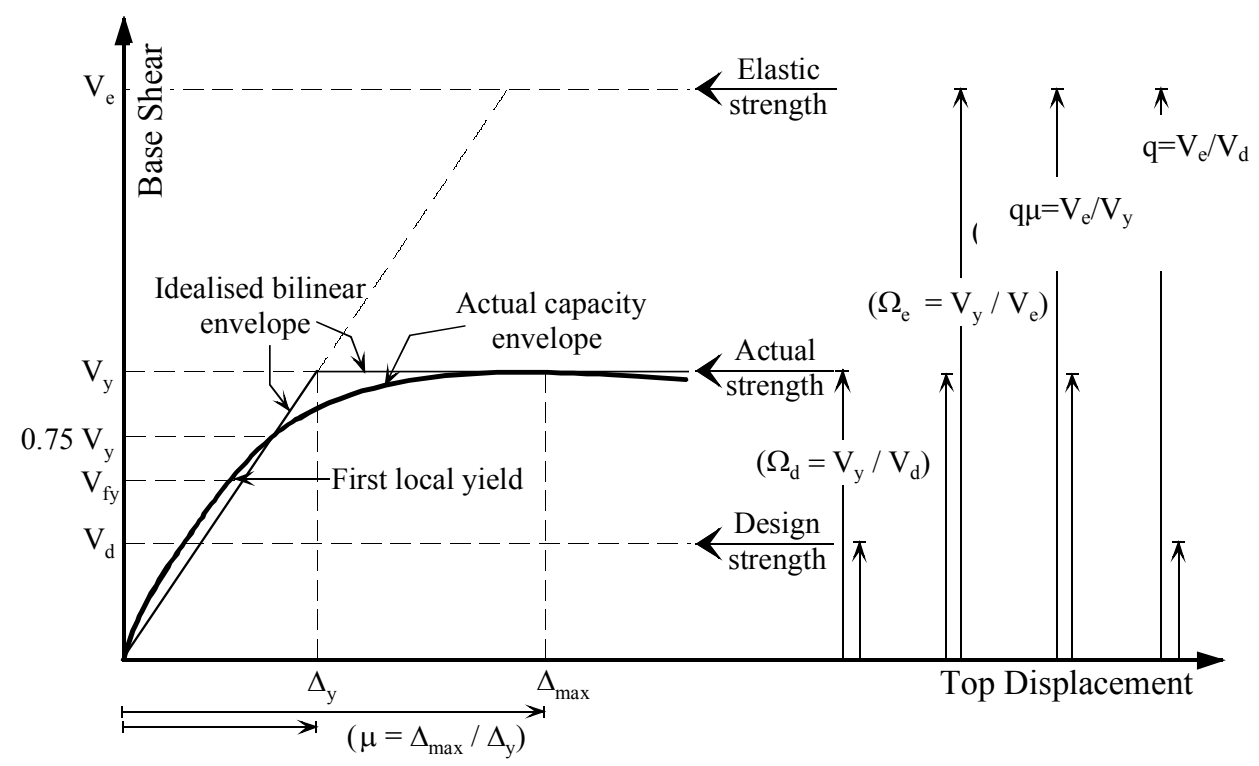

Figure9: The relationships between the force reduction factor, structural overstrength and the ductility reduction factor (Mwafy, 2001).

If an earthquake has an acceleration spectrum higher than the elastic response spectrum representing the earthquake motion in the construction zone, collapse is normally anticipated. The $\mathrm{q}$ factor is defined as the ratio between the collapse spectrum and the design spectrum of the particular accelerogram.COMMENT: Where??? Thus,

$$
\mathrm{q}_{\mathrm{c}, \mathrm{dy}}=\left(\mathrm{S}_{\mathrm{a}}\right)_{\mathrm{c}}^{\mathrm{el}} /\left(\mathrm{S}_{\mathrm{a}}\right)_{\mathrm{d}}{ }^{\text {in }}
$$

COMMENT: symbols $(\mathrm{Sa}) \mathrm{c}$,el and $(\mathrm{Se}) \mathrm{d}$,in are not defined

where, the subscripts "c" and "dy" refer to collapse and design yield (the yield level is assumed at design), respectively. The comparison of the code q-factor and the $\mathrm{q}_{\mathrm{c}, \mathrm{dy}}$ yields which should be the force reduction factor employed by the code for a cost-effective design. If $\mathrm{q}_{\mathrm{c}, \mathrm{dy}}$ is greater than the $\mathrm{q}$ factor, then the code values should increase.

If the spectral acceleration causing actual (first? to be defined...)yield is used as the definition of the design yield (what? shear?)(Elnashai and Broderick, 1996), then:

$$
\mathrm{q}_{\mathrm{c}, \mathrm{ay}}=\left(\mathrm{S}_{\mathrm{a}}\right)_{\mathrm{c}}^{\mathrm{el}} /\left(\mathrm{S}_{\mathrm{a}}\right)_{\mathrm{y}}^{\mathrm{el}}
$$


By assuming a constant dynamic acceleration amplification, $\beta_{\mathrm{o}}$, the ratios in equation (3) can be represented by the peak ground accelerations of the spectra at collapse and yield. Thus:

$$
\begin{gathered}
\mathrm{q}_{\mathrm{c}, \mathrm{dy}}=\mathrm{a}_{\mathrm{g}(\text { collapse })} /\left(\mathrm{a}_{\mathrm{g}(\text { design })} / \mathrm{q}_{\text {code }}\right) \Rightarrow \\
\mathrm{q}_{\mathrm{c}, \mathrm{dy}}=\mathrm{a}_{\mathrm{g}(\text { collapse })} / \mathrm{a}_{\mathrm{g}(\text { design yield })} \\
\mathrm{q}_{\mathrm{c}, \text { ay }}=\mathrm{a}_{\mathrm{g}(\text { collapse })} / \mathrm{a}_{\mathrm{g} \text { (actual yield })}
\end{gathered}
$$

where, $\mathrm{a}_{\mathrm{g}(\mathrm{collapse})}, \mathrm{a}_{\mathrm{g} \text { (design) }}$ and $\mathrm{a}_{\mathrm{g}(\mathrm{actual}}$ yield) are the peak ground accelerations at collapse, design

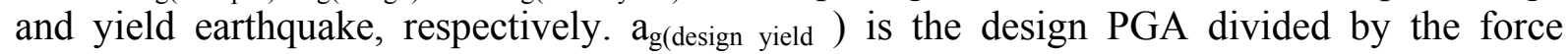
reduction factor employed by the code in the design, while $\mathrm{a}_{\mathrm{g}(\text { actual yield) }}$ is the PGA at first indication of yield.

COMMENT: why call "actual"what is "first" in Fig 9 ? Why call collapse what is "actual strength" in Fig 9? All the text is confused and confusing.

The assumption that yield occurs at the design ground acceleration divided by the force reduction factor of the code $\left(\mathrm{q}_{\text {code }}\right)$, settles the procedure of defining the force reduction factor less computational, since only the PGA of the earthquake that causes collapse is required. This definition of the force reduction factor seems to be more adequate for assessing existing force reduction factors. The validity of the design is checked by examining the capability of the structure to resist greater seismic forces than those implied by the design. The definition of $\mathrm{q}_{\mathrm{c}, \mathrm{dy}}$ has the shortcoming of not accounting for the dissimilarity between the spectral acceleration of the ground motion at yield and the design spectrum (Elnashai and Broderick, 1995).

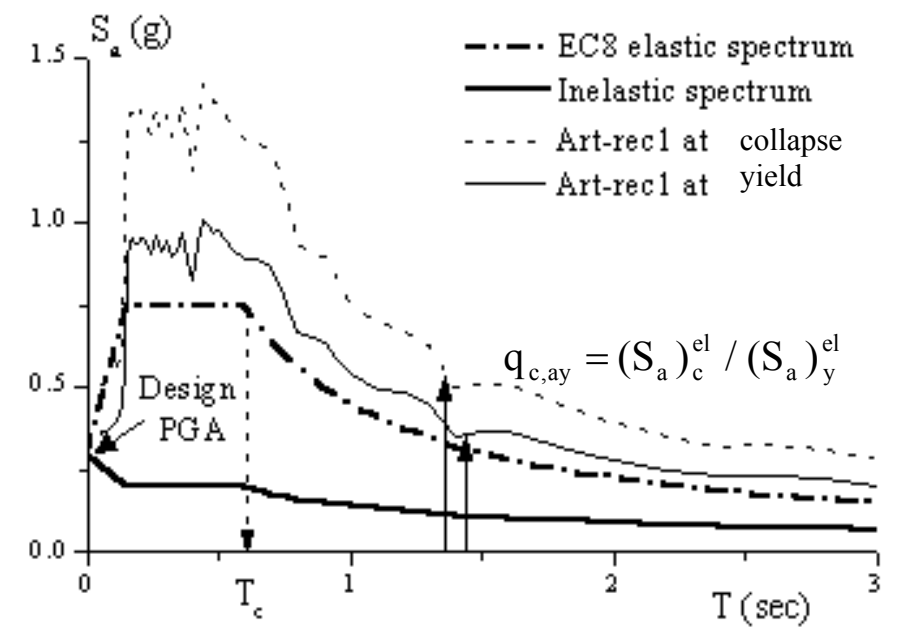

Figure 10: Evaluation of the force reduction factor $q_{c, a y}$ using Art-rec1(what's that ??).
Structures designed to modern seismic codes exhibit a considerable level of overstrength. That has as a result, the yield limit state to be generally observed at high intensity levels compared with the yield intensity implied by the design $\left(\mathrm{a}_{\mathrm{g}(\mathrm{design}}\right.$ yield $)=$ design $\mathrm{PGA} / \mathrm{q}_{\text {ode }}$ ). In all cases, the PGA causing first global (COMMENT: first or global?) yield $\left(\mathrm{a}_{\mathrm{g}}\right.$ (actual yield) $)$ is higher than both the design and elastic spectrum (Figure 10). The reason is the reserve strength of the buildings, which results in delaying the yield to this level of ground motion.

The overstrength factor is defined as the ratio between the actual yield and the design lateral strength:

$$
\Omega_{\mathrm{d}}=\mathrm{V}_{\mathrm{y}} / \mathrm{V}_{\mathrm{d}}
$$

The definition of the $\mathrm{q}_{\mathrm{c} . \mathrm{ay}}$ is more adequate for an ideal structure. The overstrength parameter should be included in the $\mathrm{q}_{\mathrm{c} \text {,ay }}$ in order to get a reliable force reduction factor. The similarity 
between the definition of $\mathrm{q}_{\mathrm{c} \text {,ay }}$ and the ductility dependent component of the force reduction factor $\left(\mathrm{q}_{\mu}=\mathrm{V}_{\mathrm{e}} / \mathrm{V}_{\mathrm{y}}\right)$, as illustrated inFigure 11, emphasizes the need to include the overstrength parameter in equations (4) and (5).

The definition of $\mathrm{q}_{\mathrm{c}, \mathrm{ay}}$, including the overstrength parameter is:

$$
\mathrm{q}_{\mathrm{c}, \text { ay }}^{\prime}=\mathrm{q}_{\mathrm{c}, \text { ay }} \cdot \Omega_{\mathrm{d}}=\left[\mathrm{a}_{\mathrm{g}(\text { collapse })} / \mathrm{a}_{\mathrm{g}(\text { actual yield })}\right] \cdot \Omega_{\mathrm{d}}
$$

The above expressions reserve the characteristics of the original definition in terms of ground

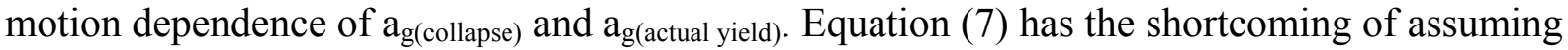
a constant dynamic amplification regardless of the structural period or the severity of earthquake.

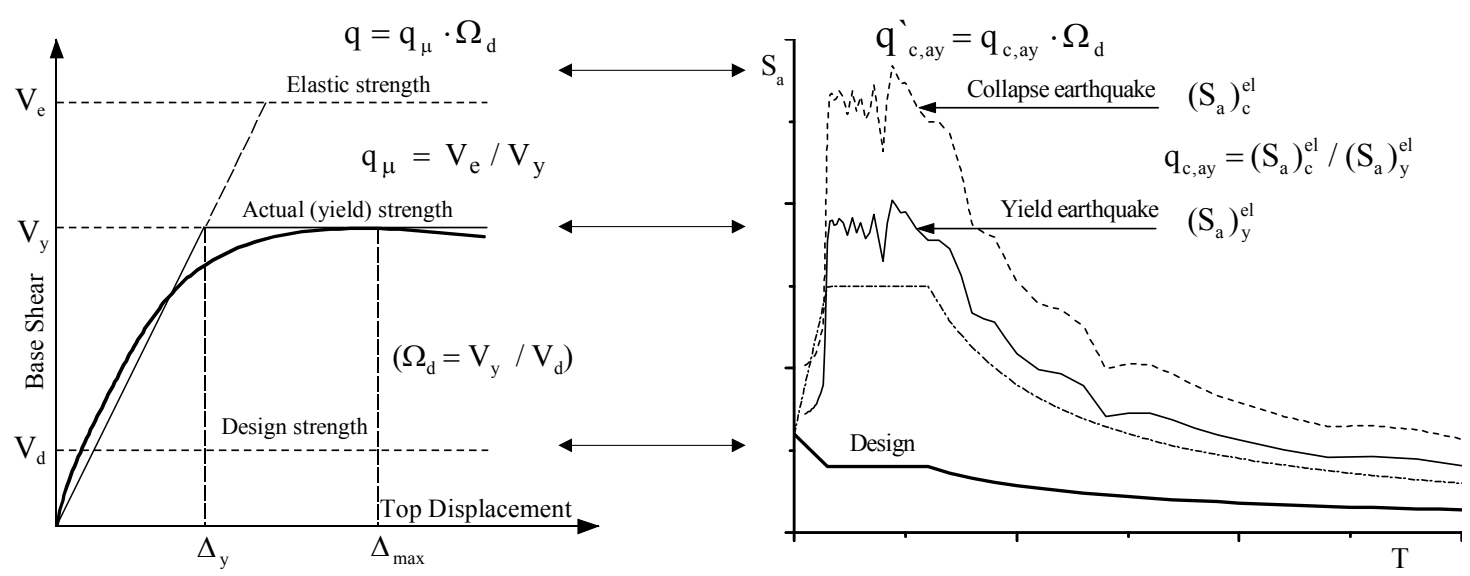

Figure11: Comparison between the ductility reduction factor $\left(q_{\mu}\right)$ and the definition of $\left(q_{c, a y}\right)$, (Mwafy, 2001).

In the current study, the definitions of equations (4) and (7) are adopted to calculate the force reduction factor. The inelastic pushover and the incremental dynamic time-history analyses are used. Pushover analysis is employed to evaluate the structural capacity and overstrength. The dynamic collapse analysis is performed under the four artificial records. Each record is scaled progressively and applied. The scaling starts at the design PGA and terminates until the yield and global limit states are achieved. This procedure gives lot of information for the structure at different levels of excitation. The whole procedure is quite time-consuming, since the models have a lot of detail. The incremental dynamic time-history analysis is performed for the second set of frames, where the solid concrete slab is used.

\section{PERFORMANCE OF COMPOSITE FRAMES}

Eigenvalue analysis is carried out for the two sets of frames. The periods of vibration provide a first insight into the response of the building. The results from eigenvalue analysis are presented in Table.

\begin{tabular}{|c|c|c|c|c|c|c|}
\hline \multirow{2}{*}{$\begin{array}{c}\text { Set of } \\
\text { Frames }\end{array}$} & \multirow{2}{*}{$\begin{array}{c}\text { Type of } \\
\text { Frame }\end{array}$} & \multicolumn{5}{|c|}{ Observed Elastic Periods (secs) } \\
\cline { 3 - 7 } & $\mathbf{T}_{1}$ & $\mathbf{T}_{2}$ & $\mathbf{T}_{3}$ & $\mathbf{T}_{4}$ & $\mathbf{T}_{5}$ \\
\hline
\end{tabular}




\begin{tabular}{|c|c|c|c|c|c|c|}
\hline \multirow{3}{*}{ 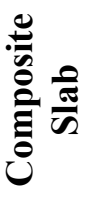 } & (A) & 0.989 & 0.365 & 0.237 & 0.048 & 0.032 \\
\hline & (B) & 0.715 & 0.233 & 0.135 & 0.097 & 0.051 \\
\hline & (C) & 0.861 & 0.283 & 0.159 & 0.107 & 0.079 \\
\hline \multirow{3}{*}{$\begin{array}{l}\frac{0}{\pi} \\
\frac{\pi}{n} \\
\frac{\sigma}{\sigma} \\
\mathscr{n}\end{array}$} & (A) & 1.127 & 0.385 & 0.232 & 0.151 & 0.059 \\
\hline & (B) & 0.926 & 0.285 & 0.152 & 0.102 & 0.048 \\
\hline & (C) & 1.278 & 0.392 & 0.205 & 0.126 & 0.085 \\
\hline
\end{tabular}

Table4: Periods of vibrations for the six frames considered

(A): 4-storey frame non-seismic design, (B): 4-storey frame seismic design $\left(\mathrm{a}_{\mathrm{g}}=0.2 \mathrm{~g}\right)$

(C): 8 -storey frame seismic design $\left(\mathrm{a}_{\mathrm{g}}=0.4 \mathrm{~g}\right)$

COMMENT: T3, T4, T5 are probably meaningless and associated with low modal masses, so suppress those 3 columns; but put definition of frames A,B,Cinside the Table

From the above results, it can be said that composite frames are flexible structures and exhibit fundamental periods much higher than the corner period at the plateau $T_{B}=0.5$ seconds. The response of the first set of frames is stiffer than that of the second set because of the bigger cross-sections adopted.

In global structural systems, the stiffness of the column members is one of the most important parameters governing lateral resistance. The period of a frame depends on the mass and the stiffness of each member. The natural period elongates by increasing the weight of the structure and shortens by increasing the stiffness. In general, composite frames with fully or partially encased columns have longer natural periods compared with bare steel frames. This means that the effect of increasing the mass is greater than that of increasing stiffness when equivalent composite columns replace bare steel columns.

Furthermore, composite frames are required to resist lower base shears. The longer fundamental period yields a smaller design base shear. Thus, the gravity loads govern the design and the action effects introduced by the seismic forces become less significant.

The structure is subjected to incremental lateral loads using the triangular distribution, which is closer to the first mode distribution. The lateral forces are monotonically increased with a combination of load and displacement control until the target displacement is reached. The target displacement has been considered the $5 \%$ of the total height of the building.

The increasing branch can be divided into two parts. The first part, which represents the phase of elastic behaviour, extends from the origin until the point of first yielding. From this point begins the second part of the increasing branch, which develops due to the plastic redistribution capacity of the structure until collapse (Figure 12). The pushover curve provides enough information about the global ductility of the structure. At each load step the designer is able to check the member behaviour and see if the limit states are fulfilled. The weak areas and the formation of the plastic hinges are revealed during the analysis.
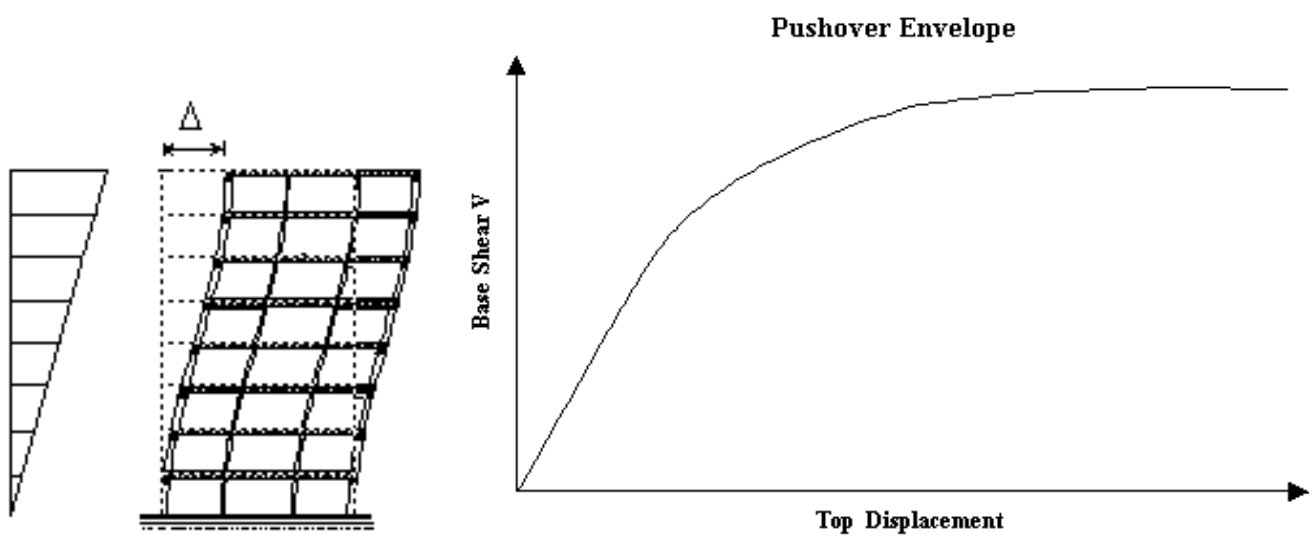
Figure12: Inelastic static pushover curve - Triangular distribution.

The results of the inelastic pushover analysis are presented for both sets of frames in Table and Table.

\begin{tabular}{|c|c|c|c|c|c|}
\hline $\begin{array}{c}\text { Frames with } \\
\text { Composite Slab }\end{array}$ & $\mathbf{V}_{\mathbf{y}}(\mathbf{k N})$ & $\mathbf{V}_{\mathbf{d}}(\mathbf{k N})$ & $\begin{array}{c}\text { Overstrength } \\
\left(\mathbf{\Omega}_{\mathbf{d}}\right)\end{array}$ & $\mathbf{q}_{\text {code }}$ & $\mathbf{\Omega}_{\mathbf{i}}=\mathbf{\Omega}_{\mathbf{d}} / \mathbf{q}_{\text {code }}$ \\
\hline (A) & 668 & 336 & 1.98 & 1 & 1.98 \\
\hline (B) & 1814 & 168 & 10.8 & 4 & 2.70 \\
\hline (C) & 1912 & 260 & 7.35 & 6 & 1.23 \\
\hline
\end{tabular}

Table5: Results of the inelastic pushover analysis - First set of frames

(A): 4-storey frame non-seismic design, (B): 4-storey frame seismic design $\left(\mathrm{a}_{\mathrm{g}}=0.2 \mathrm{~g}\right)$

(C): 8-storey frame seismic design $\left(\mathrm{a}_{\mathrm{g}}=0.4 \mathrm{~g}\right)$

\begin{tabular}{|c|c|c|c|c|c|}
\hline $\begin{array}{c}\text { Frames with } \\
\text { Solid Slab }\end{array}$ & $\mathbf{V}_{\mathbf{y}}(\mathbf{k N})$ & $\mathbf{V}_{\mathbf{d}}(\mathbf{k N})$ & $\begin{array}{c}\text { Overstrength } \\
\left(\boldsymbol{\Omega}_{\mathbf{d}}\right)\end{array}$ & $\mathbf{q}_{\text {code }}$ & $\boldsymbol{\Omega}_{\mathbf{i}}=\mathbf{\Omega}_{\mathbf{d}} / \mathbf{q}_{\text {code }}$ \\
\hline (A) & 384 & 226 & 1.70 & 1 & 1.70 \\
\hline (B) & 546 & 69 & 7.91 & 4 & 1.98 \\
\hline (C) & 880 & 164 & 5.36 & 6 & 0.89 \\
\hline
\end{tabular}

Table6: Results of the inelastic pushover analysis - Second set of frames

(A): 4-storey frame non-seismic design, (B): 4-storey frame seismic design $\left(\mathrm{a}_{\mathrm{g}}=0.2 \mathrm{~g}\right)$

(C): 8 -storey frame seismic design $\left(\mathrm{a}_{\mathrm{g}}=0.4 \mathrm{~g}\right)$

According to Mwafy, 2001, an additional measure that relates the actual $\left(\mathrm{V}_{\mathrm{y}}\right)$ to the elastic strength level $\left(\mathrm{V}_{\mathrm{e}}\right)$ is suggested. This new proposed measure $\left(\Omega_{\mathrm{i}}\right)$, the inherent overstrength factor, may be expressed as:

$$
\Omega_{\mathrm{i}}=\mathrm{V}_{\mathrm{y}} / \mathrm{V}_{\mathrm{e}}=\Omega_{\mathrm{d}} / \mathrm{q}
$$

The suggested measure of response $\left(\Omega_{\mathrm{i}}\right)$ reflects the reserve strength and the anticipated behaviour of the structure under the design earthquake. In case of $\Omega_{\mathrm{i}}>1$ the global response of the structure will be almost elastic under the design earthquake reflecting the high overstrength of the structure. When $\Omega_{\mathrm{i}}<1$ the ratio of forces that are imposed on the structure in the post-elastic range is equal to $\left(1-\mathrm{V}_{\mathrm{y}} / \mathrm{V}_{\mathrm{e}}\right)$.

The strength levels for both sets of frames exceed the elastic strength with the exception of the eight-storey frame of the second set. As it can be seen in Figure 13, the second frame of each group exhibits a larger observed and inherent overstrength. For frame (B), which is designed for a lower q factor than frame (C), the values of $\Omega_{\mathrm{i}}$ are consistent with the results of the overstrength factor $\left(\Omega_{\mathrm{d}}\right)$. 
The inelastic static pushover analysis yields large overstrength factors. In order to check the validity and the accuracy of the inelastic static pushover analysis results, the incremental dynamic collapse analysis is employed. The idealised envelopes obtained from time-collapse analysis are compared with the pushover envelopes for two load patterns, the inverted triangular (code) and the rectangular (uniform) shapes.

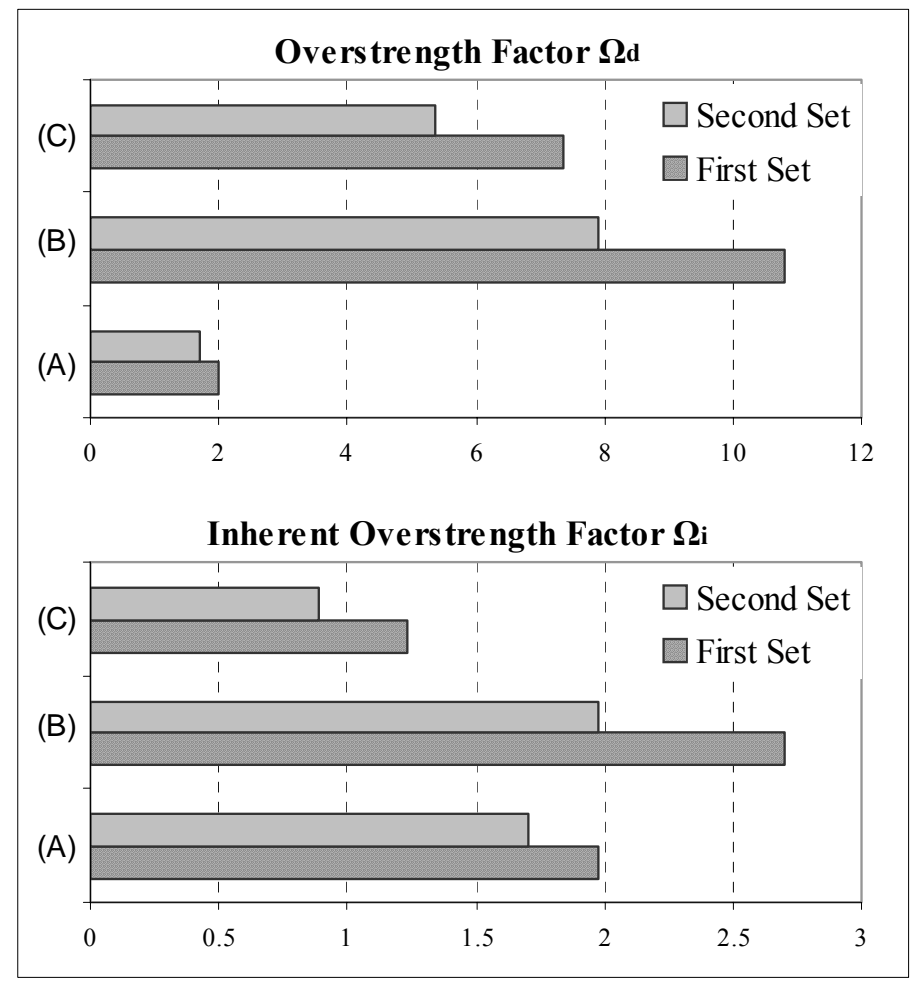

First Set: Frames with Composite Slab Second Set: Frames with Solid Slab (A): 4-storey frame non-seismic design (B): 4-storey frame seismic design $\left(\mathrm{a}_{\mathrm{g}}=0.2 \mathrm{~g}\right)$ (C): 8-storey frame seismic design $\left(\mathrm{a}_{\mathrm{g}}=0.4 \mathrm{~g}\right)$

Figure13: Comparison between $\left(\Omega_{\mathrm{d}}\right)$ and $\left(\Omega_{\mathrm{i}}\right)$ overstrength factor.

InFigure 15, a representative case is shown. It is frame (B) of the second set of frames, which has exhibited a quite high overstrength factor $\left(\Omega_{\mathrm{d}}=7.91\right)$. The lateral force profile influences the structural response. The use of the uniform load shape yields a pushover curve that reaches higher values compared with the pushover curve obtained by applying a triangular load shape. The idealized envelope of the time-collapse analysis is placed above the other two curves. This difference would be smaller if the utilized artificial accelerogram was based on the new EC8 elastic spectrum. As it has already been mentioned, the artificial accelerograms utilized were made to fit the current elastic EC8 spectrum, which is more conservative compared with the new elastic EC8 spectrum (prEN 1998-1-1:2001). 


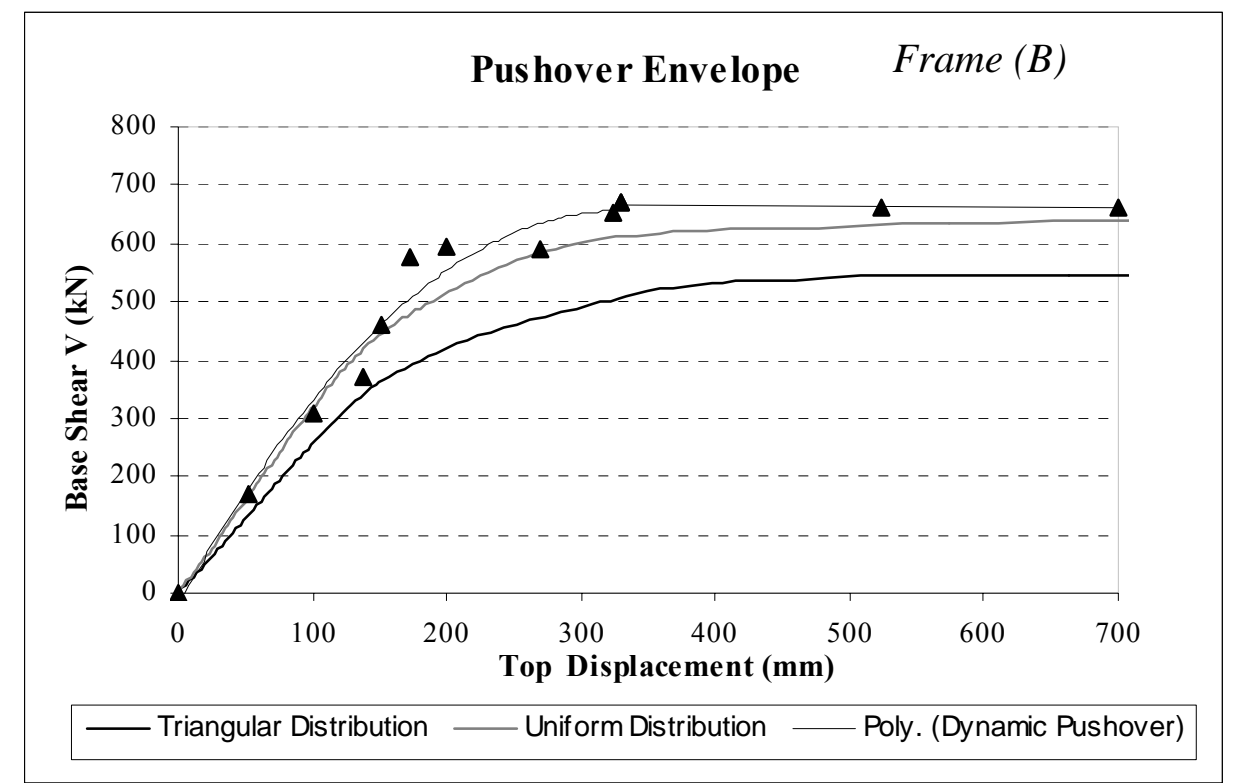

Figure15: Comparison between the Dynamic Pushover and the Inelastic Static Pushover.

(B): 4-storey frame seismic design $\left(\mathrm{a}_{\mathrm{g}}=0.2 \mathrm{~g}\right)$

From the above, it is concluded that the dynamic collapse and inelastic static pushover analyses give comparable results.

The estimated overstrength factors $\left(\Omega_{\mathrm{d}}\right)$ depicted in Figure 15show that the values of overstrength obtained from inelastic static pushover analyses are high. The same behaviour is observed in both sets of frames. The main reasons that may have contributed at reaching these unusually high values of overstrength are:

1. As far as the first set of frames is concerned, the restriction imposed by the bearing length of composite slabs requirement is very significant. The design of the frames is controlled by this limitation of the steel beam size.

2. The assumption made that second order effects are not taken into account imposed severe limitations on the selection of the composite beams and columns cross-sections. The lateral resistance of a moment resisting frame depends mainly on the stiffness of the columns. Hence, in order to control the interstorey drift and in sequence the stability index $\theta$ the size of the columns has been increased, until the satisfaction of the limits.

3. Composite frames have long natural periods compared to reinforced concrete frames of the same height. This means that they are designed for low base shears. This is more applicable to the second set of frames, since the natural periods are even longer. Hence, the seismic forces do not govern the design.

4. Some particular checks in the beams such as the resistance to vertical shear $\left(\mathrm{V}_{\mathrm{sd}} / \mathrm{V}_{\mathrm{pl}, \mathrm{Rd}} \leq 0.5\right)$ and the shear buckling resistance which should be greater than the resistance to vertical shear $\left(\mathrm{V}_{\mathrm{b}, \mathrm{Rd}} \geq \mathrm{V}_{\mathrm{pl}, \mathrm{Rd}}\right)$ imposed further restriction on the steel beam size. In addition, the local ductility of members which dissipate energy by their work in compression or bending should be ensured by restricting the width-thickness ratio $b / t$, according to the cross sectional classes. The relationship between the behaviour factor $\mathrm{q}$ and the cross sectional class imposes a limitation on the size of the beam.

5. The necessity of using commercial sections leads to a remarkable increase in the member sizes. This increase becomes more significant if the capacity design criterion is employed, since columns cross-sections are selected based on the resistant capacity of the beams. In addition, the composite members are designed to resist the maximum actions effects along the beam length. That means that the supply is constant, although the demand may vary 
along the beam length. This design concept is conservative but on the other hand, it provides a more efficient and economical way of construction.

6. The assumptions made in the modelling with Sap2000Nonlinear may have altered the behaviour of the frame. The fact that the composite beam has the same behaviour in positive and negative moment leads to a different redistribution of moments.

7. The stiffness of the beam, which is related to the effective width, may be another factor. For frame (A), which is designed for non-seismic forces, the moment of inertia is taken equal to the positive moment of inertia (cross-section subjected to positive moment). No cracking is taken into account. For the remaining frames designed to resist seismic forces, EC8 (prEN 1998-1-1:2001) suggests formulae for the calculation of the inertia for both composite beams and columns, where cracking is taken into account. These assumptions are conservative, but are in the safe side.

8. The strain hardening and the difference between the characteristic values of material strengths, used for the design, and the mean values of material strengths, used for the analysis, are some other factors contributing to the large observed overstrength.

\section{SEISMIC RESPONSE OF COMPOSITE FRAMES}

The incremental dynamic-to-collapse analysis is employed for the evaluation of the force reduction factor for the frames of the second set (solid slabs). Four artificially generated records are selected. These records were generated to fit the current EC8 elastic spectrum for medium soil class "Firm Class" (EN 1998-1-1:1994). Their duration is 10 seconds. The artificial accelerograms are scaled progressively up to the satisfaction of the limit states. The results at global yield and collapse are presented.

The global yield criterion employed in the analysis is based on the yield point defined in the actual force-deformation envelope taken from the pushover analysis. The global yield intensities observed from dynamic analysis for each record are shown inTable 7.

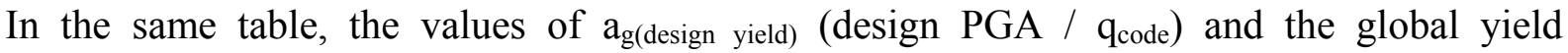
intensities for the four ground motions divided by $\mathrm{a}_{\mathrm{g} \text { (design yield) }}$ are also presented. The ratio ( $\mathrm{a}_{\mathrm{g} \text { (actual yield) }} / \mathrm{a}_{\mathrm{g} \text { (design yield) }}$ ) between the average peak ground acceleration that causes actual yield and the intensity at which yield is implied in the design exceeds unity, reflecting the high overstrength exhibited by the buildings.

In all cases, the structure yielding is observed at high intensity levels compared with $\mathrm{a}_{\mathrm{g}(\mathrm{design}}$ yield). For frames (B) and (C), designed for seismic actions, the comparison between the

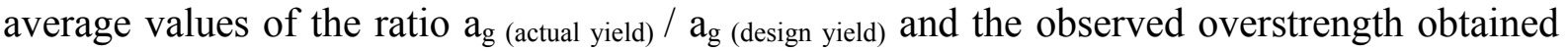
from inelastic static pushover analysis shows that, employing $\Omega_{d}$ in the definition of the force reduction factor suggested in equation (7) is generally conservative ( $\mathrm{a}_{\mathrm{g} \text { (actual yield) }} / \mathrm{a}_{\mathrm{g} \text { (design yield) }}$ $\left.>\Omega_{\mathrm{d}}\right)$.

COMMENT: in the following table use, instead of Art-1, write"Artificial Accelerogram 1 PGA and give unit $(\% \mathrm{~g}$ ?)

\begin{tabular}{|c|c|c|c|}
\hline Frame & (A) & (B) & (C) \\
\hline \multirow{2}{*}{ Art - 1 } & 0.450 & 0.539 & 0.600 \\
\hline Art - 2 & 0.284 & 0.449 & 0.920 \\
\hline
\end{tabular}




\begin{tabular}{|c|c|c|c|}
\hline Art - 3 & 0.373 & 0.420 & 0.860 \\
\hline Art - 4 & 0.315 & 0.425 & 0.837 \\
\hline $\mathbf{a}_{\mathrm{g} \text { (design yield) }}$ & 0.220 & 0.055 & 0.073 \\
\hline Art - 1 & 2.045 & 9.800 & 8.182 \\
\hline Art - 2 & 1.290 & 8.164 & 12.546 \\
\hline $\begin{array}{c}\overline{5} \\
\overline{2}\end{array}$ Art - 3 & 1.695 & 7.636 & 11.723 \\
\hline$\sigma^{50} \sigma^{50}$ Art -4 & 1.432 & 7.727 & 11.414 \\
\hline Average & 1.615 & 8.332 & 10.966 \\
\hline $\mathbf{\Omega}_{\mathrm{d}}$ & 1.700 & 7.910 & 5.360 \\
\hline
\end{tabular}

Table7: Ground accelerations at global yield limit state.

(A): 4-storey frame non-seismic design, (B): 4-storey frame seismic design $\left(\mathrm{a}_{\mathrm{g}}=0.2 \mathrm{~g}\right)$ (C): 8 -storey frame seismic design $\left(\mathrm{a}_{\mathrm{g}}=0.4 \mathrm{~g}\right)$

The interstorey drift (ID) criterion is the global collapse parameter that is utilised to evaluate the force reduction factors. In Table 8the ground motions at collapse limit state are shown. In addition, the average ratios of $\mathrm{a}_{\mathrm{g} \text { (collapse) }} / \mathrm{a}_{\mathrm{g} \text { (design) }}$ for the four ground motions are presented. The ratio reflects the average margin of safety exhibited by each frame under the effect of the four ground motions.

\begin{tabular}{|c|c|c|c|}
\hline Frame & (A) & (B) & (C) \\
\hline Art - 1 & 0.520 & 0.660 & 0.735 \\
\hline 产 $\quad$ Art - 2 & 0.400 & 0.579 & 0.965 \\
\hline $\int_{5}^{\infty} \quad$ Art - 3 & 0.455 & 0.533 & 0.992 \\
\hline Art - 4 & 0.432 & 0.572 & 0.885 \\
\hline $\mathbf{a}_{\mathrm{g}}$ (design) & 0.220 & 0.220 & 0.440 \\
\hline \multirow{5}{*}{ 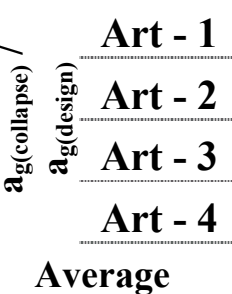 } & 2.364 & 3.000 & 1.670 \\
\hline & 1.818 & 2.632 & 2.193 \\
\hline & 2.068 & 2.423 & 2.254 \\
\hline & 1.964 & 2.600 & 2.011 \\
\hline & 2.054 & 2.664 & 2.032 \\
\hline
\end{tabular}

Table8: Ground accelerations at collapse limit state

(A): 4-storey frame non-seismic design, (B): 4-storey frame seismic design $\left(\mathrm{a}_{\mathrm{g}}=0.2 \mathrm{~g}\right)$ (C): 8-storey frame seismic design $\left(\mathrm{a}_{\mathrm{g}}=0.4 \mathrm{~g}\right)$

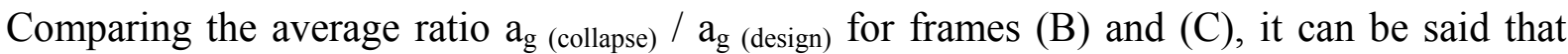
there is a tendency the margin of safety to increase with the decrease in the design ground acceleration. This could be more obvious if the frames compared had the same configuration and ductility. This may be attributed to the high contribution of gravity loads in buildings designed to low PGA. The balance between gravity and seismic design scenarios is the main parameter controlling this margin

For the evaluation of the behaviour factor $(\mathrm{q})$ the definitions of $\mathrm{q}_{\mathrm{c}, \mathrm{dy}}$ and $\mathrm{q}_{\mathrm{c} \text {,ay }}^{\prime}$ are utilised. The results are presented in Table 9, 10 and 11 for frames (A), (B) and (C) respectively. Moreover, the average supply-to-demand ratios are also presented. 


\begin{tabular}{|c|c|c|c|c|c|}
\hline Frame (A) & Art - 1 & Art - 2 & Art - 3 & Art - 4 & Average \\
\hline \hline $\mathbf{a}_{\mathbf{g} \text { (collapse) }}$ & 0.520 & 0.400 & 0.455 & 0.432 & 0.452 \\
\hline $\mathbf{a}_{\mathbf{g}(\text { actual yield) }}$ & 0.450 & 0.284 & 0.373 & 0.315 & 0.356 \\
\hline $\left.\mathbf{\Omega}_{\mathbf{d}}\right)$ & 1.700 & 1.700 & 1.700 & 1.700 & 1.700 \\
\hline $\mathbf{q}_{\text {c,ay }}^{\prime}$ & $\mathbf{1 . 9 6 4}$ & $\mathbf{2 . 3 9 4}$ & $\mathbf{2 . 0 7 3}$ & $\mathbf{2 . 3 3 1}$ & $\mathbf{2 . 1 9 0}$ \\
\hline $\mathbf{q}_{\text {c,ay }}^{\prime} / \mathbf{q}$ & 1.964 & 2.394 & 2.073 & 2.331 & 2.190 \\
\hline Frame (A) & Art - 1 & Art - 2 & Art - 3 & Art - 4 & Average \\
\hline \hline $\mathbf{a}_{\mathbf{g} \text { (collapse) }}$ & 0.520 & 0.400 & 0.455 & 0.432 & 0.452 \\
\hline $\mathbf{a}_{\mathbf{g}(\text { design yield) }}$ & 0.220 & 0.220 & 0.220 & 0.220 & 0.220 \\
\hline $\mathbf{q}_{\mathbf{c}, \text { dy }}$ & $\mathbf{2 . 3 6 4}$ & $\mathbf{1 . 8 1 8}$ & $\mathbf{2 . 0 6 8}$ & $\mathbf{1 . 9 6 4}$ & $\mathbf{2 . 0 5 4}$ \\
\hline $\mathbf{q}_{\mathbf{c}, \text { dy }} / \mathbf{q}$ & 2.364 & 1.818 & 2.068 & 1.964 & 2.054 \\
\hline
\end{tabular}

Table9: Force reduction factor $q_{\text {,dy }}$ and $q_{c, \text { ay }}^{\prime}$ for frame (A).

(A): 4-storey frame non-seismic design

\begin{tabular}{|c|c|c|c|c|c|}
\hline Frame (B) & Art - 1 & Art - 2 & Art - 3 & Art - 4 & Average \\
\hline $\mathbf{a}_{\mathbf{g} \text { (collapse) }}$ & 0.660 & 0.579 & 0.533 & 0.572 & 0.585 \\
\hline $\mathbf{a}_{\mathbf{g} \text { (actual yield) }}$ & 0.539 & 0.449 & 0.420 & 0.425 & 0.458 \\
\hline $\left.\mathbf{\Omega}_{\mathbf{d}}\right)$ & 7.910 & 7.910 & 7.910 & 7.910 & 7.910 \\
\hline $\mathbf{q}_{\text {c,ay }}^{\prime}$ & $\mathbf{9 . 6 8 6}$ & $\mathbf{1 0 . 2 0 0}$ & $\mathbf{1 0 . 0 3 8}$ & $\mathbf{1 0 . 6 4 6}$ & $\mathbf{1 0 . 1 4 3}$ \\
\hline $\mathbf{q}_{\mathbf{c}, \mathbf{a y}}^{\prime} / \mathbf{q}$ & 2.421 & 2.550 & 2.509 & 2.661 & 2.535 \\
\hline Frame (B) & Art - 1 & Art - 2 & Art - 3 & Art - 4 & Average \\
\hline \hline $\mathbf{a}_{\mathbf{g} \text { (collapse) }}$ & 0.660 & 0.579 & 0.533 & 0.572 & 0.586 \\
\hline $\mathbf{a}_{\mathbf{g} \text { (design yield) }}$ & 0.055 & 0.055 & 0.055 & 0.055 & 0.055 \\
\hline $\mathbf{q}_{\mathbf{c}, \text { dy }}$ & $\mathbf{1 2 . 0 0 0}$ & $\mathbf{1 0 . 5 2 7}$ & $\mathbf{9 . 6 9 0}$ & $\mathbf{1 0 . 4 0 0}$ & $\mathbf{1 0 . 6 5 4}$ \\
\hline $\mathbf{q}_{\mathbf{c}, \mathbf{d y}} / \mathbf{q}$ & 3.000 & 2.632 & 2.422 & 2.600 & 2.664 \\
\hline
\end{tabular}

Table10: Force reduction factor $q_{\text {,dy }}$ and $q_{c, \text { ay }}^{\prime}$ for frame (B).

(B): 4-storey frame seismic design $\left(\mathrm{a}_{\mathrm{g}}=0.2 \mathrm{~g}\right)$

The first thing which can be observed is the high values of the force reduction factor "supply" compared to the values suggested by EC8. Frame (A) is designed for $\mathrm{q}=1$ (elastic design) and the average calculated behaviour factors $\mathrm{q}_{\mathrm{c}, \mathrm{dy}}$ and $\mathrm{q}_{\mathrm{c} \text {,ay }}^{\prime}$ are equal to 2.05 and 2.19, respectively. The second frame (B), is designed for $\mathrm{q}=4$ and the average behaviour factors obtained from the analysis $\mathrm{q}_{\mathrm{c}, \mathrm{dy}}$ and $\mathrm{q}_{\mathrm{c}, \text { ay }}$ are equal to 10.654 and 10.143 , respectively. For the last frame $(\mathrm{C})$, which is designed for $\mathrm{q}=6$, the average value of $\mathrm{q}_{\mathrm{c} \text {,ay }}^{\prime}$ is equal to the design behaviour factor, whereas the value of $\mathrm{q}_{\mathrm{c}, \mathrm{dy}}$ is equal to 12.250 .

\begin{tabular}{|c|c|c|c|c|c|}
\hline Frame (C) & Art - 1 & Art - 2 & Art - 3 & Art - 4 & Average \\
\hline \hline $\mathbf{a}_{\mathbf{g} \text { (collapse) }}$ & 0.735 & 0.965 & 0.992 & 0.885 & 0.894 \\
\hline $\mathbf{a}_{\mathrm{g} \text { (actual yield) }}$ & 0.600 & 0.920 & 0.860 & 0.837 & 0.804 \\
\hline$\left(\mathbf{\Omega}_{\mathrm{d}}\right)$ & 5.360 & 5.360 & 5.360 & 5.360 & 5.360 \\
\hline
\end{tabular}




\begin{tabular}{|c|c|c|c|c|c|}
\hline $\mathbf{q}_{\mathbf{c}, \mathbf{a y}}^{\prime}$ & $\mathbf{6 . 5 6 6}$ & $\mathbf{5 . 6 2 2}$ & $\mathbf{6 . 1 8 2}$ & $\mathbf{5 . 6 6 7}$ & $\mathbf{6 . 0 0 9}$ \\
\hline $\mathbf{q}_{\mathbf{c}, \mathbf{a y}}^{\prime} / \mathbf{q}$ & 1.094 & 0.937 & 1.030 & 0.944 & 1.001 \\
\hline Frame (C) & Art - 1 & Art - 2 & Art - 3 & Art - 4 & Average \\
\hline \hline $\mathbf{a}_{\mathbf{g} \text { (collapse) }}$ & 0.735 & 0.965 & 0.992 & 0.885 & 0.894 \\
\hline $\mathbf{a}_{\mathbf{g}(\text { design yield) }}$ & 0.073 & 0.073 & 0.073 & 0.073 & 0.073 \\
\hline $\mathbf{q}_{\mathbf{c}, \text { dy }}$ & $\mathbf{1 0 . 0 6 8}$ & $\mathbf{1 3 . 2 1 9}$ & $\mathbf{1 3 . 5 8 9}$ & $\mathbf{1 2 . 1 2 3}$ & $\mathbf{1 2 . 2 5 0}$ \\
\hline $\mathbf{q}_{\mathbf{c}, \text { dy }} / \mathbf{q}$ & 1.678 & 2.203 & 2.265 & 2.020 & 2.042 \\
\hline
\end{tabular}

Table11: Force reduction factor $q_{\text {,dy }}$ and $q_{\text {c,ay }}^{\prime}$ for frame (C).

(C): 8-storey frame seismic design $\left(\mathrm{a}_{\mathrm{g}}=0.4 \mathrm{~g}\right)$

Secondly, when comparing the supply-to-design values obtained by the two definitions of $\mathrm{q}_{\mathrm{c}, \mathrm{dy}}$ and $\mathrm{q}_{\mathrm{c}, \mathrm{ay}}^{\prime}$, the former definition in general yields higher values. This can be explained by

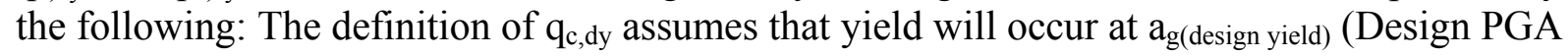
/ $\mathrm{R}_{\text {code }}$ ), which implicitly accounts for overstrength at the yield level. This definition is insensitive to the ground motion characteristics and hence to the yield intensity of the structure. The second definition $\mathrm{q}_{\mathrm{c} \text {,ay }}^{\prime}$ employs the actual yield intensity corrected by the

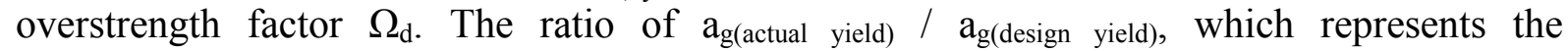
overstrength assumed in the definition of $\mathrm{q}_{\mathrm{c}, \mathrm{dy}}$, is generally higher than the actual overstrength $\Omega_{\mathrm{d}}$, as shown inTable 7 . Therefore, average values of $\mathrm{q}_{\mathrm{c}, \mathrm{dy}}$ are higher than $\mathrm{q}_{\mathrm{c}, \mathrm{ay}}^{\prime}$.

Frame $\mathrm{C}$ has the highest difference between the $\mathrm{q}_{\mathrm{c}, \text { ay }}^{\prime}$ and the $\mathrm{q}_{\mathrm{c}, \mathrm{dy}}$ expression. The $\mathrm{q}_{\mathrm{c} \text {,ay }}^{\prime}$ expression yields values equal to the design behaviour factor, whereas the $\mathrm{q}_{\mathrm{c}, \mathrm{dy}}$ expression yields values about two times the design behaviour factor. This difference can be justified by taking into account the values of the ratio $\mathrm{a}_{\text {(actual yield) }} / \mathrm{a}_{\text {(design yield) }}$ and the overstregth factor. FromTable 7 , the ratio $\mathrm{a}_{\text {(actual yield) }} / \mathrm{a}_{\text {(design yield) }}$ is equal to 10.966 , while $\Omega_{\mathrm{d}}$ is equal to 5.360 .

The evaluation of the force behaviour factor "supply" depends on the selection of the performance criteria. In this study, only global performance criteria are taken into account. There is an approximation in the definition of the global yield, which may lead to a conservative global yield point. That means that the behaviour factors could have taken higher values. Hence, the selection of the performance criteria is a very significant step in the definition of the force reduction factor.

In general, the definition $\mathrm{q}_{\mathrm{c}, \mathrm{ay}}^{\prime}$ is more conservative compared to the $\mathrm{q}_{\mathrm{c}, \mathrm{dy}}$ definition. Especially in the case of frame $(\mathrm{C})$, the $\mathrm{q}_{\mathrm{c} \text {, ay }}^{\prime}$ value is equal to the code reduction factor. In the case of frames (A) and (B), the difference between the average values of the two definitions is small. This is because the difference between the overstrength $\Omega_{\mathrm{d}}$ and the ratio $\mathrm{a}_{\text {(actual yield) }} /$ $\mathrm{a}_{\text {(design yield) }}$ is small. Hence, the two definitions can provide comparable force reduction factors, if the overstrength $\Omega_{\mathrm{d}}$ obtained by inelastic pushover analysis is close to the ratio

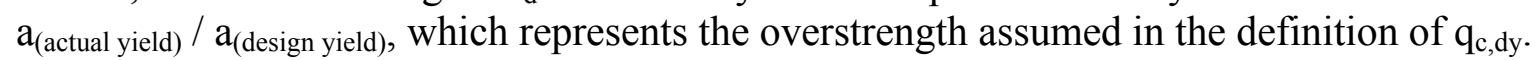

\section{CONCLUSIONS}

Undertaking full and detailed design using the new drafts of EC8 and EC4 (seismic design and composite structures) has lead to the identification of several clauses that may require improvements or even correction, in the case of EC4. The most important case is the lateral- 
torsional buckling check of the composite beams, as discussed in the body of the paper. There is an acute need for clear and fast design expressions in this respect. Moreover, it is difficult to have a continuous composite slab spanning four meters, since the shear connection check (full shear connection) cannot be satisfied. Hence, if the solution of stopping the steel sheeting at the beam is chosen, then the guideline that defines the required bearing length is very strict. The limitation imposed on the beam size is severe and the whole design is governed by construction constraints. In practice, other construction methods are used and the code should provide the designer with alternatives that will lead to a more efficient and economical design.

One of the main observations from the analysis is the high overstrength exhibited by the frames. This is due to design code constraints on section selection, such as second order effects $(\theta \leq 0.1)$, leading to grossly over-conservative design outcome.

The 'observed overstrength factor' $\left(\Omega_{\mathrm{d}}\right)$ may lead to unreliable predictions of the true overstrength, due to the inclusion of the design force reduction in its definition. In addition, it fails to confirm clearly the conservatism of the code since its variation is too wide. In contrast, the 'inherent overstrength factor' $\left(\Omega_{\mathrm{i}}\right.$; Mwafy, 2001, Elnashai and Mwafy, 2002) has the advantage of excluding the code force reduction factor and depends only on the actual and elastic strength of the structure. Hence, it reflects in a better way the anticipated behaviour of the structure and the reserve strength under the design earthquake.

The calculated force reduction factors ("supply") exhibit higher values compared to the code suggested values (q). Therefore values of force reduction factors in EC8 can be increased without adverse effects on structural safety.

COMMENT: sorry, I will not support such a general conclusion on the basis of one limited study.

It is noteworthy that the frame designed elastically $(\mathrm{q}=1)$ and without capacity design exhibited a force reduction factor "supply" greater than unity. It is therefore capable of absorbing seismic energy is a stable manner. This observation is very significant and has implication on both the EC4 and EC8. Specifically, force reduction factors in the range of 1.5 for non-seismically designed structures, which are now stated in EC8, are confirmed; many modern existing structures may therefore be exempt from upgrading.

If the existing design criteria are retained, the design of composite frames is controlled by gravity loads. Therefore, the imposition of capacity design (especially column overstrength) is not necessary and leads to gross conservatism..

COMMENT: this has not been shown. Design with $\mathrm{q}=1$ has been shown safe. Design with higher $\mathrm{q}$ and capacity design have been shown safe; Design with high q and not capacity design has not been studied. So I will not support this conclusion.

\section{REFERENCES}

COMMENT: ICONS report must be one reference

Astaneh-Asl, A., 1994, "Seismic design of composite structures in the United States", Broderick, B.M. and Elnashai, A.S., 1996, "Seismic response of composite frames - I. Response criteria and input motion”, Engineering Structures, Vol. 18 (9), p.696-706.

Broderick, B.M., "Seismic testing, analysis, and design of composite frames", $\mathrm{PhD}$ Thesis, Imperial College, London, UK. 
Calderoni, B., Rauso, and D.,Ghersi, A., 1994, "Statistical evaluation of the behaviour factor for steel frames", Stessa'94, p. 278-288.

Deierlein, G and Hsieh, S.-H., 1990, "Seismic response of steel frames with semirigid connections using the capacity spectrum method", Proceedings of the $4^{\text {th }}$ U.S. National Conference on Earthquake Engineering , 2, p. 863-872.

EC2, Eurocode No 2, "Design of concrete structures", European Committee for standardization, 2nd Draft, prEN 1992-1, January 2001.

EC3, Eurocode No 3, "Design of steel structures", European Committee for standardization, $1^{\text {st }}$ Draft, prEN 1993-3:2000, $6^{\text {th }}$ December 2000.

EC4, Eurocode No 4, "Design of composite steel and concrete structures", European Committee for standardization, 3rd Draft, prEN 1994-1-1:2001, April 2001.

EC8, Eurocode No 8, "Design of structures for earthquake resistance", European Committee for standardization, 3rd Draft, prEN 1998-1-1:2001, Mav 2001.

Elghazouli, A.Y., 1991, "Earthquake resistance of composite beam-columns", PhD Thesis, Imperial College, London, UK.

Elnashai, A.S. and Broderick, B.M., 1996, "Seismic response of composite frames II. Calculation of behaviour factors", Engineering Structures, Vol. 18 (9), p. 707-723.

Elnashai, A.S. and Elghazouli, A.Y., 1993, "Performance of composite steel/concrete members under earthquake loading, Part I: Analytical Model", Earthquake Engineering and Structural Dynamics, Vol. 22 (4), p. 315-345.

Elnashai, A.S. and Mwafy, A.M., 2001, "Overstrength and force reduction factors of multi-storey RC buildings", Accepted for publication in The Structural Design of Tall Buildings, March 2001.

Elnashai, A.S., Broderick, B.M. and Dowling, P.J., 1995, "Earthquake-resistant composite steel/concrete structures", The Structural Engineer, Vol. 73 (8), p. 121-132.

Elnashai, A.S., Broderick, B.M., 1995, "Eurocode 8 - Requirements for the seismic design of composite structures", $10^{\text {th }}$ European Conference on Earthquake Engineering, Rotterdam, Holland.

Fajfar, P., 1999, "Capacity spectrum method based on inelastic demand spectra", Earthquake Engineering and Structural Dynamics, Vol. 28, p. 979-993.

Freeman, S.A., 1998, "Development and use of capacity spectrum method", Proceedings of the $6^{\text {th }}$ U.S. National Conference on Earthquake Engineering, Seattle, Washington.

Hamburger, R.O., Foucth, D. and Cornell, C.A., 2000, "Performance basis of guidelines for evaluation upgrade and design of moment-resisting steel frames", Proceedings of $12^{\text {th }}$ World Conference on Earthquake Engineering, Auckland, New Zealand.

Johnson, R.P., 1994, “Composite structures of steel and concrete, Volume 1, Beams, slabs, columns, and frames for buildings", second edition, Oxford Blackwell Scientific Publications.

Kappos, A.J., 1999, "Evaluation of behaviour factors on the basis of ductility and overstrength studies”, Engineering Structures, Vol. 21 (9), p. 823-835.

Mazzolani, F.M. and Piluso, V., 1996, "Theory and design of seismic resistant steel frames", first edition, Chapman \& Hall, London.

Mwafy, A.M., 2001, "Seismic performance of code-designed RC buildings", PhD Thesis, Imperial College, London, UK.

Mwafy, A.M., and Elnashai, A.S., 2001, "Static pushover versus dynamic collapse analysis of RC buildings", Engineering Structures, Vol. 23 (5), p. 407-424.

Elnashai, A.S. and Mwafy, A.M., 2002, 'Overstregth and force reduction factors for RC Buildings', Journal of Structural Design of Tall Buildings, vol., pp.

Plumier, A., 1994, “Codification: General Report”, Stessa '94, p. 441-447. 
Plumier, A., 2000, "General report on local ductillity", Journal of Constructional Steel Research, 55, p. 91-107.

Rossetto, T., 2001, PhD Transfer Report, "Vulnerability Curves for the Seismic Assessment of RC Buildings", Imperial College. 